Bartın Üniversitesi

Eğitim Fakültesi Dergisi

Cilt 5, Sayı 3, s. 652-668, Ekim 2016

BARTIN - TÜRKIYE

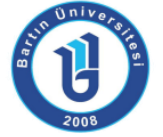

ISSN: 1308-7177
Bartin University

Journal of Faculty of Education

Volume 5, Issue 3, p. 652-668, October 2016

BARTIN - TURKEY

Doi: 10.14686/buefad.v5i3.5000189030

\title{
Does Preschool Education Help Immigrant Children Reach Their Native Peers' Academic Levels? A Case of Turkish Immigrant Children in Sweden*
}

Mehmet TORAN, Yrd.Doç.Dr., i̇stanbul Kültür Üniversitesi Eğitim Fakültesi, m.toran@iku.edu.tr

\begin{abstract}
The disadvantages associated with immigration put the children of immigrant families at risk for academic failure. This study investigates the efficacy of educational support provided by the Swedish preschool system to the children of the Turkish families who migrated to Sweden. In this study non-equivalent control group design was used. The sample of the study consists of a total of $45 ; 5$ years old preschool children, 23 Swedish children and 22 Turkish children receiving native language support. During the research both groups continued attending regular public preschool program. Bracken Basic Concept Scale - Revised Form was used as a data collection tool. The results demonstrated that the Swedish preschool education programme was effective in supporting Swedish and Turkish children's concept acquisition and school readiness. Nevertheless, the programme was not able to close the gap significantly between the Turkish and Swedish children's concept acquisition and school readiness observed prior to program implementation.
\end{abstract}

Key Words: preschool education, Immigrant children, Swedish preschool education, school readiness, concept acquisition, mother tongue support

\section{Okul Öncesi Eğitim Göçmen Çocukların Yerli Akranlarının Akademik Düzeylerine Erişmelerini Destekler Mi? İsveç’teki Göçmen Türk Çocuklarının Durumu}

Öz: Göç olgusu ile birlikte ortaya çıkan dezavantajlar göçmen aile çocuklarının akademik başarılarını risk altına almaktadır. Mevcut araştırmada İsveç'e göç etmiş Türklerin çocuklarına İsveç okul öncesi eğitim sisteminde sunulan eğitsel desteğin etkililiği araştırılmaktadır. Araştırmada yöntem olarak eşitlenmemiş kontrol gruplu desen kullanılmıştır. Araştırmanın çalışma grubunu 23'ü İsveçli ve 22'si Türk olup anadili desteği alan 5 yaşında toplam 45 çocuk oluşturmaktadır. Araştırma süresince her iki grupta devlet okuluna devam etmektedir. Araştırmada veri toplama aracı olarak Bracken Temel Kavram ÖlçeğiGözden Geçirilmiş Formu kullanılmıştır. Araştırmanın sonuçları İsveç okul öncesi programının hem İsveç hem de Türk çocukların kavram edinimleri ve okula hazırlık düzeyleri üzerinde etkili olduğunu göstermiştir. Ancak buna rağmen, uygulanan programın Türk ve İsveçli çocukların kavram edinimi ve okula hazırlık bulunuşluk puanları arasındaki farkı kapatamadığı gözlenmiştir.

Anahtar Sözcükler: okul öncesi eğitim, göçmen çocukları, İsveç okul öncesi eğitimi, okula hazırlık, kavram edinimi, anadili desteği

\footnotetext{
* Supported by Swedish Institute
} 


\section{INTRODUCTION}

Immigrant families and their children encounter many challenges in their host countries. Cultural incompatibility, acceptance as immigrants (Heath, Rothon \& Kilpi, 2008; Knocke, 2000; Rumbaut, 2007), working at low wage jobs that require no skills and the consequent economic problems directly affect the family as well as the child (Behtoui, 2004; OECD, 2010). The children of immigrant families do not only face the disadvantages of immigration, but at the same time they face difficulties in academic and social life (Passel, 2011; Shields \& Behrmen, 2004; Tienda \& Haskins, 2011). Disadvantages such as; the lowincome, the low standards of social welfare, unemployment or part-time working undereducated parents (Mistry, Biesanz, Chien, Howes \& Benner, 2008), crowded family structure, the protection of the cultural background, insufficient parenting skills directly affect the immigrant child (Schnepf, 2008). The fact that the immigrant families do not frequently utilize the public space, participate in the parent education activities in particular and the reality that the education of children is not maintained adequately in the home environment along with depriving children of high quality time affect children's academic and social lives in the family (Shields \& Behrmen 2004; Passel, 2011). Assimilation and discrimination resulting from immigration influences the immigrant families negatively, thus decreases the level of life satisfaction (Liebkind, Jasinskaja-Lahti \& Solheim, 2004). Assimilation prevents the immigrant family to be engaged in the social and economic spheres with its own identity, compels a struggle to fit into the society the family has immigrated to and thus leads the family to live without having completely forsaken its own identity while denying a complete adaptation of the new cultural identity. Without doubt, this has negative effects on the family's life satisfaction. In the same line as the argument above, the fact of immigration exposes the immigrant family to cultural, economic, social class and ethnic discrimination thus affecting the levels of life satisfaction for all family members in a negative way (Dietz, 2010; OECD, 2013; Safi, 2010). The low levels of life satisfaction cause the immigrant family to be indifferent/negligent about the child, to disregard the child's academic life and ignore meeting the child's needs in fulfilling manner and therefore leads to the negative effects on the child's social and academic life (Dronkers, 2010; Fossati, 2011; Jonsson \& Rudolphi, 2011; Rindermann \& Ceci, 2009; Schnepf, 2008).

Studies with the children of the immigrant families suggest that immigrant children are at risk. Children of the immigrants are facing poverty and they are affected very negatively from the disadvantages of this poverty (Beiser, Hou, Hyman \& Tousignant, 2002). Poverty also causes that these children face privation as well. This privation blocks the children from benefiting from a rich stimulant environment and receiving high quality education (Cohen, Deterding \& Clewell, 2005; Eurydice, 2009; Tienda \& Haskins, 2011). The children of the newly immigrated families show lower academic performance (European Commission, 2013). The immigrant families' children perform poorly in the areas of literacy and mathematics (Schnepf, 2008) and the immigrant children show lower academic performance in general, particularly in the first year of schooling. The concept of immigration besides affecting negatively children's school success, also influences adversely the number of children continuing their education (Becker, Klein \& Biedinger, 2013).

While the children's cognitive, social and conceptual acquisitions may be affected by many different factors either positively or negatively; they may also be directly and negatively affected by such a factor as immigration (Fröhlich, Petermann \& Metz, 2013). It is a fact that the immigrant children cannot receive adequate academic encouragement from their families.

The ethnic discrimination occurs at schools lead to academic insufficiency and influences the children's cognitive development negatively when compared to their local 
peers. Along with this, the immigrant child that is trapped between the predominant language at home and the language spoken at the public space may not acquire either languages and therefore experience deficiency in the language development. The body of research reveal that the developmental deficiencies experienced in cognitive and lingual domains directly affect the child's conceptual acquisition (Schonewille \& van der Leij, 1993; Yazıcı, Genç ilter \& Glover, 2010; Wilson, Dickinson \& Rowe, 2013). Maneva (2004), states that a social environment rich of linguistic stimulus offered to multi lingual children has a positive effect on their language acquisition and facilitates their cognitive development. According to researches and reports supporting the children's development at the maximum level turns the disadvantageous situations into advantages. For this reason, it is aimed to develop the early intervention programmes for the immigrant families' children.

Policy documents on immigrant children suggest that the educational programmes must be designed in the best possible way to help children benefit from the early childhood education at the maximum level. Educational programmes protecting immigrant children from discrimination to maximize their gain benefit from education, supporting immigrant parents at home and school, applying bilingual programs, meeting children's developmental needs by considering the disadvantages of children sourced from their immigrant status are being designed and implemented with positive results (Matthews \& Even, 2010; OECD, 2006; OMEP, 2013; UNICEF, 2004). The OECD reports indicate Sweden as an example country where children fully exercise their right to education and where children of immigrant families can access education at the highest levels (OECD 2001; OECD, 2011; Taguma, Litjens \& Makowiecki, 2013). Some of the studies claim that although the immigrant children receive high quality education, the education system still cannot meet the developmental needs and contributes to their academic success.

The early childhood education programs that are geared toward children of immigrant families should facilitate children's adaptation into the new country and their future life and support their cognitive, social and academic skills (Glind van de, 2010; Whitehead, Hashim \& Iversen, 2007). On the other hand, the family's being second or third generation of immigrants, and the development of the region/country hint at the academic lives of the immigrant children. Bracken, Sabers and Insko (1987), found that Afro-American children's concept acquisition and their level of school readiness are much lower than the Euro-American children. It was also found out that that ethically disadvantaged children were slow to acquire the concepts and school readiness level compared to the children who are not disadvantaged (Stebbish \& Mclntosh, 1996). Wilson (2004), indicated that there was no difference between the concept acquisition and school readiness level of the children under risk who attended two different early intervention programmes, Head start and Perry preschool project, and the programmes specially designed for children turned the socioeconomic disadvantages into advantages and supported the cognitive skills. McCartney, Dearing, Taylor and Bub (2007), discovered that the school readiness level, receptive and expressive language skills of immigrant children with socioeconomic disadvantage were lower than their peers with high socioeconomic status. Dotterer, Iruka and Pungello (2012), worked with the Afro-American and Euro-American children and found that the children's school readiness level differs according to their socioeconomic level and that the school readiness level is in favour of the children with low socioeconomic status. Nevertheless, cultural background is an influential factor in the children's school readiness performance. Loeb, Fuller, Kagan, and Carrol (2004) found that the early intervention programmes provided to the children with socioeconomic disadvantage has a positive effect on the children's cognitive development and supports their academic skills in a positive way. 
Sweden has a sizeable population of immigrants and issued many legal regulations for the social, cultural and economic adaptation of immigrants. According to report number 325 by the Swedish Ministry of Education a special budget is set apart for the immigrants who live in Sweden to learn their mother tongue and about 2600 children between the ages of 0-6 who migrated from Turkey to Sweden benefit from this service (Skolverket, 2009).

Sweden is one of the top rated OECD countries in terms of qualitative early childhood education and formal education (Pramling Samuelsson \& Sheridan, 2009). In Sweden children at the age of $1-5$ benefit from the preschool education while children at the age of 6 (for this age preschool education is compulsory) benefit from integrated preschool education (Korpi, 2007). The programme integration of these two systems was developed in parallel with compulsory school programme (Skolverket, 2008a) and the educational system was composed democratically. In Swedish preschool education programme, it is expected that the children are expected to learn respecting each other, be open, solidarity, being accountable, being empathic, inquiry skills, ethical values, thinking deeper about the daily life problems and acquire the skill to provide solutions to those problems, understanding that all individuals around them are equal and respecting all life around them and acquire the notion of responsibility (Skolverket, 2008b). The programme emphasizes that for children language and knowledge are connected to each other. It is stressed that acquiring the language facilitates and creates a bridge for the children to acquire knowledge and skills. Thus, learning and improving their mother tongue will help children with different ethnic background in learning Swedish language easier and in acquiring the knowledge in both languages easily (Skolverket, 2008b). Children speaking Swedish and those speaking different languages are supported with language, art and play activities in terms of self-expression, vocabulary expansion, concept acquisition, and communication skills, which support the development of their cultural identity (National Agency for Education, 2006; Skolverket, 2011). In Swedish pre-school institutions a budget to receive native language education is allocated by the municipalities and the same time staff, curriculum and coordination are also provided. In the pre-school institutions, the parents demand from the municipalities to receive the native language support and the local administrations realize the necessary facilitation. The appointment of the native language teacher is managed by the municipality and the principle criterion for the teacher is that he/she holds a native language proficiency certificate that covers two years of study at the university. However, it is also debated that there are uncertainties regarding the proficiency levels of the native language teachers and that the municipalities cannot find teachers with required proficiency levels (Lindberg, 2007; Skolverket, 2008a; Warren, 2013).

The native language activities are implemented according to the annual plan of the native language teacher by adhering to the preschool's general activities. According to this plan the activities include reading stories, playing finger games, tongue twisters, singing songs, reciting poems and vocal exercises. The child participates in the native language activities separately from the other children in the class and when the activity is over continuing other activities by joining his/her group in the class (Skolverket, 2008a).

The early childhood education programmes designed to support mother tongue, besides supporting the children's developmental areas, have a potential to foster the disadvantaged children's cognitive skills (Rao, Sun, Zhou \& Zhang, 2012). Early concept acquisition facilitates children's adaptation to their environment and promotes their abstract thinking skills (Üstün \& Akman, 2003; Vosniadou, Pagondiotis \& Deliyianni, 2005). Moreover, the concept acquisition is related both to the children's language skills and to school readiness thus the development in the concept acquisition directly affects these two important areas. The conceptual acquisitions of children affect their receptive and expressive lingual skills, 
improve the expression of thought in abstract and play a crucial role on children's academic skills. Previous studies have shown that children attending preschool gain considerable improvement in all developmental areas, including concept acquisition, which is related to the school readiness (Bracken \& Crawford, 2010; Fleer \& Raban, 2006; Toran \& Temel, 2012). In this study school readiness is defined as the preparing the child for an advanced learning environment by supporting the child's academic life and developmental domains with appropriate stimulants. School readiness consists of cognitive, social, emotional and psychomotor skills and the academic and cultural proficiencies that are related to these (Bracken, 1998). The studies (Becker et al., 2013; De Feyter \& Winsler, 2009; Magnuson, Lahaie \& Waldfogel, 2006) reveal that the fact of immigration is one of the basic reasons why the school preparation levels of immigrant families' children who are regarded as the disadvantaged group are lower than their peers.

As it would be seen from the research done (Becker et al., 2013; Dotterer et al., 2012; Magnuson et al., 2006), the disadvantages associated with the immigration has a negative effect on the children's knowledge construction, school readiness level, and concept acquisition. The immigration negatively and mostly effects early childhood years which are very critical (Fossati, 2011; Jonsson \& Rudolphi, 2011; Loeb et al., 2004). Young children are very vulnerable and they are exposed to the adverse effects of immigration. These effects hinder children from understanding the world, organizing themselves cognitively, expressing themselves and academically achieving success. Therefore, examining the concept acquisition and school readiness level of the immigrant families' children is crucial. Thus, the present study aimed to investigate the effects of the Swedish preschool education programme with mother tongue support on the children's school readiness level and concept acquisition

\section{METHOD}

\subsection{Research design}

In this study non-equivalent control group design was used. The non-equivalent control group design is probably the most frequently used design in social research (Cook \& Campbell, 1979). It is structured like a pre-test and post-test randomized experiment, but it lacks the key feature of the randomized designs -- random assignment. In the non-equivalent control group design, researcher most often use intact groups that $s /$ he thinks are similar as the treatment and control groups (Cook \& Campbell, 1979).

\subsection{Research group}

The study group was composed of children who study in the same class and 8 different government preschools in Gothenburg. The sample was composed of $45 ; 5$ years old children, 23 Swedish children (11 girls, 12 boys) and 22 Turkish immigrant children ( 13 girls, 9 boys). Turkish children were selected from the children of the immigrant families who chose to have mother tongue support during their preschool education and who were second and third generations. Swedish children were selected from same preschool classes where Turkish children educated.

\subsection{Instrumentation}

Bracken Basic Concept Scale-Revised (BBCS-R) was used as a data collection tool. BBCS$R$ was developed by Bruce A. Bracken (1984), and was then revised in 1998. BBCS-R is composed of 11 subscales and 308 items. The subscales include school readiness, direction/position, self/social awareness, texture/material, quantity, and time/sequence (Bracken, 1998). BBCS-R's items present pictures of four situations on each page. It is expected from the child to select the picture that is appropriate to the question asked. It takes about 20 
to 45 minutes to administer the BBCS-R. BBCS-R was translated from the original English to Swedish by a language expert and later the scale was adapted after the consultations of two language experts. The BBCS-R Swedish form is applied to both study groups. In order to test reliability, the BBCS-R was administered on 59 children different from the study group and Cronbach's Alpha reliability coefficients of the subscales were calculated; school readiness 0.74 , direction/position 0.75 , self/social awareness 0.78 , texture/material 0.79 , quantity 0.77 , and time/sequence 0.79 . Cronbach's Alpha reliability of the entire BBCS-R scale was found to be 0.91 . These results demonstrated that the reliability coefficients calculated for the subscales and the entire scale is adequate.

\subsection{Data Collection}

The research covered approximately 7 months from November to May period. During the research no special program was applied, the study only investigated the effects of the Swedish preschool education program on the concept acquisition and school readiness of the children from families with sociocultural differences such as immigration and native situation. Turkish and Swedish children were measured at the beginning and at the end of the educational year. To form the research group, a written permission is granted by the children's parents, the school and the local administration; children's descent is also considered. That is, the children who do not want to be included in the research group are excluded despite the written permission. The scale used in the research was adapted to Swedish so the data collection was done with an assistant who has degree in Swedish and has an excellent command of the language and bachelor's degree in pedagogy. The children were individually interviewed. The children were asked by the research assistant to point at the appropriate picture among the four different pictures prepared for each item. The researcher then coded each answer of the children on the response sheet.

\subsection{Data Analysis}

Firstly, data was analyzed for normality. The result show that the test scores all subtests score found normality in both groups. Then the parametric analysis was used. Because of the existence of two independent groups (Swedish and Turkish children) and time (pre-test and post-test), two-way repeated MANOVA test was used. All test assumptions (linearity, multivariate normality and homogeneity of variance/covariance) were checked and met prior to data analysis (Ho, 2006). In order to control for type I error rate Bonferroni correction was used. The significance level was set at 0.05 .

\section{RESULTS and DISCUSSION}

In order to investigate the effects of the Swedish preschool education program on the concept acquisition of 5 years old Turkish and Swedish children, BBCS-R was used in November (pre-test) and in May (post-test). The arithmetic mean and standard deviation values are presented in table 1.

Table 1

The Arithmetic Mean and Standard Deviation Values of the Subscales of the BBCS-R Applied to the 5 Years Old Turkish and Swedish Children Who Benefit from the Swedish Preschool Education Program

\section{Swedish ( $\mathrm{n}=23)$}

\begin{tabular}{lrrrrrrrr}
\cline { 2 - 9 } & \multicolumn{2}{c}{ Pre-test } & \multicolumn{2}{c}{ Post-test } & \multicolumn{2}{c}{ Pre-test } & \multicolumn{2}{c}{ Post-test } \\
\cline { 2 - 10 } & Mean & SD & Mean & SD & Mean & \multicolumn{1}{c}{ SD } & Mean & \multicolumn{1}{c}{ SD } \\
\hline School Readiness & 49.55 & 15.33 & 60.36 & 15.51 & 37.09 & 18.72 & 44.82 & 20.21 \\
\hline Direction/Position & 38.18 & 16.12 & 44.55 & 12.57 & 19.18 & 9.55 & 29.45 & 14.82 \\
\hline Self/Social Awareness & 29.18 & 5.10 & 31.27 & 5.33 & 21.09 & 10.10 & 25.00 & 7.63 \\
\hline
\end{tabular}




\begin{tabular}{lrrrrrrrr}
\hline Texture/Material & 18.45 & 6.64 & 23.09 & 3.83 & 12.73 & 6.94 & 14.73 & 7.62 \\
\hline Quantity & 29.55 & 8.03 & 35.82 & 7.37 & 18.73 & 13.32 & 25.91 & 11.89 \\
\hline Time/Sequence & 16.73 & 7.35 & 23.45 & 8.10 & 10.73 & 5.16 & 18.00 & 6.80 \\
\hline
\end{tabular}

When Table 1 is examined it can be seen that there are considerable differences between Swedish and Turkish children's pre-test and post-test scores favoring Swedish children. There are also differences between the arithmetic mean values of the pre-test and post-test scores and it could be seen that the differences are modest and the level of improvement between the two groups is approximately similar. In order to examine whether the observed differences between Swedish and Turkish children's scores from the six subscales of BBCS-R are statistically significant, MANOVA (two-way repeated MANOVA) statistics was performed and the results are shown in table 2 .

Table 2

The Results of the Two-Way Repeated MANOVA (Pillai Trace) Survey Applied to the Scores of the BBCS-R of the Swedish and Turkish Children Attending the Preschool Education Programs in Sweden

\begin{tabular}{lccccccr}
\hline Source & $\Lambda_{\text {Pillai }}$ & $\mathbf{F}$ & Hypothesis df & Error df & $\mathbf{p}$ & $\mathbf{\eta}^{2}$ & Power \\
\hline Group & .76 & 2.58 & 6 & 18 & .159 & .76 & .39 \\
\hline Time & .96 & 17.66 & 6 & 18 & $.003^{*}$ & .96 & 1.00 \\
\hline Group* Time & .62 & 1.34 & 6 & 18 & .382 & .62 & .21 \\
\hline
\end{tabular}

${ }^{*} \mathrm{p}<0.05$

The results of the MANOVA test demonstrated that there are statistically significant differences between the pre-test and post-test BBCS-R scores of the Swedish and Turkish children $\left(\Lambda_{\text {Pillai }}=.96 ; F_{6,18}=17.66 ; p=.003\right)$ with a large effect size $\left(\eta^{2}=.96\right)$. These results suggest that the Swedish preschool education program is effective both on Swedish and Turkish children's concept acquisition and school readiness. Subsequently, follow up analysis of the BBCS-R subscales using the ANOVA (Green House Geiser) statistics was performed, the results are provided in Table 3.

Table 3

The Results of the ANOVA (Green House Geiser) Tests Performed on the Subscale Scores of the BBCS-R of the Children Attending the Swedish Preschool Education Program

\begin{tabular}{|c|c|c|c|c|c|c|c|c|}
\hline Source & Subscales & $\begin{array}{l}\text { Sum of } \\
\text { Squares }\end{array}$ & df & $\begin{array}{l}\text { Mean } \\
\text { Square }\end{array}$ & $\mathbf{F}$ & $\mathbf{p}$ & $\eta^{2}$ & Power \\
\hline \multirow{6}{*}{ Group } & School Readiness & 2156.00 & 1 & 2156.00 & 6.45 & $.029^{*}$ & .39 & .63 \\
\hline & Direction/Position & 3196.02 & 1 & 3196.02 & 17.84 & $.002^{*}$ & .64 & .97 \\
\hline & Self/Social Awareness & 567.36 & 1 & 567.36 & 10.24 & $.009^{*}$ & .51 & .82 \\
\hline & Texture/Material & 546.02 & 1 & 546.02 & 10.75 & $.008^{*}$ & .52 & .84 \\
\hline & Quantity & 1181.45 & 1 & 1181.45 & 13.16 & $.005^{*}$ & .57 & .90 \\
\hline & Time/Sequence & 360.82 & 1 & 360.82 & 10.64 & $.009^{*}$ & .52 & .84 \\
\hline \multirow{6}{*}{$\begin{array}{l}\text { Error } \\
\text { (Group) }\end{array}$} & School Readiness & 3342.50 & 43 & 334.25 & & & & \\
\hline & Direction/Position & 1791.23 & 43 & 179.12 & & & & \\
\hline & Self/Social Awareness & 554.14 & 43 & 55.41 & & & & \\
\hline & Texture/Material & 507.73 & 43 & 50.77 & & & & \\
\hline & Quantity & 897.55 & 43 & 89.75 & & & & \\
\hline & Time/Sequence & 339.18 & 43 & 33.92 & & & & \\
\hline \multirow{6}{*}{ Time } & School Readiness & 945.82 & 1 & 945.82 & 45.54 & $.001^{*}$ & .82 & 1.00 \\
\hline & Direction/Position & 761.11 & 1 & 761.11 & 14.95 & $.003^{*}$ & .60 & .94 \\
\hline & Self/Social Awareness & 99.00 & 1 & 99.00 & 13.11 & $.005^{*}$ & .57 & .90 \\
\hline & Texture/Material & 121.11 & 1 & 121.11 & 5.56 & $.040^{*}$ & .36 & .57 \\
\hline & Quantity & 497.82 & 1 & 497.82 & 22.31 & $.001^{*}$ & .69 & .99 \\
\hline & Time/Sequence & 539.00 & 1 & 539.00 & 19.11 & $.001^{*}$ & .66 & .98 \\
\hline
\end{tabular}




\begin{tabular}{|c|c|c|c|c|c|c|c|c|}
\hline \multirow{6}{*}{$\begin{array}{l}\text { Error } \\
\text { (Time) }\end{array}$} & School Readiness & 207.68 & 43 & 20.77 & & & & \\
\hline & Direction/Position & 509.14 & 43 & 50.91 & & & & \\
\hline & Self/Social Awareness & 75.50 & 43 & 7.55 & & & & \\
\hline & Texture/Material & 217.64 & 43 & 21.76 & & & & \\
\hline & Quantity & 223.18 & 43 & 22.32 & & & & \\
\hline & Time/Sequence & 282.00 & 43 & 28.20 & & & & \\
\hline \multirow{6}{*}{$\begin{array}{l}\text { Group * } \\
\text { Time }\end{array}$} & School Readiness & 26.27 & 1 & 26.27 & .93 & .357 & .09 & .14 \\
\hline & Direction/Position & 42.02 & 1 & 42.02 & .72 & .415 & .07 & .12 \\
\hline & Self/Social Awareness & 9.09 & 1 & 9.09 & 1.70 & .221 & .15 & .22 \\
\hline & Texture/Material & 19.11 & 1 & 19.11 & 2.16 & .173 & .18 & .26 \\
\hline & Quantity & 2.27 & 1 & 2.27 & .09 & .773 & .01 & .06 \\
\hline & Time/Sequence & .82 & 1 & .82 & .05 & .832 & .00 & .05 \\
\hline \multirow{6}{*}{$\begin{array}{l}\text { Error } \\
\text { (Group * } \\
\text { Time) }\end{array}$} & School Readiness & 282.23 & 43 & 28.22 & & & & \\
\hline & Direction/Position & 582.23 & 43 & 58.22 & & & & \\
\hline & Self/Social Awareness & 53.41 & 43 & 5.34 & & & & \\
\hline & Texture/Material & 88.64 & 43 & 8.86 & & & & \\
\hline & Quantity & 260.73 & 43 & 26.07 & & & & \\
\hline & Time/Sequence & 173.18 & 43 & 17.32 & & & & \\
\hline
\end{tabular}

$* p<.05$

The results demonstrated that the group - time interaction in all of the subscales of the BBCS-R were not statistically significant ( $p>.05)$. On the other hand, it is seen that both the group and the time main effects were statistically significant. The results indicated that the differences between Swedish and Turkish children were statistically significant in terms of the scores acquired from the subscales of the BBCS- $R$ (School Readiness $\left[F_{1,43}=6.45, p=.029\right]$; Direction/Position $\quad\left[F_{1,43}=17.84, p=.002\right] ;$ Self/Social Awareness $\left[F_{1,43}=10.24, p=.009\right]$; Texture/Material $\left[\mathrm{F}_{1,43}=10.75, \mathrm{p}=.008\right]$; Quantity $\left[\mathrm{F}_{1,43}=13.16, \quad \mathrm{p}=.005\right]$; Time/Sequence $\left.\left[\mathrm{F}_{1,43}=10.64, \mathrm{p}=.009\right]\right)$. Swedish children were more likely to obtain higher scores than Turkish children.

The results also indicated statistically significant differences between pre-test and post-test assessments (School Readiness $\left[\mathrm{F}_{1,43}=45.54, \mathrm{p}=.000\right.$ ]; Direction/Position $\left[\mathrm{F}_{1,43}=14.95\right.$, $\mathrm{p}=.003$ ]; Self/Social Awareness [ $\left.\mathrm{F}_{1,43}=13.11, \mathrm{p}=.005\right]$; Texture/Material $\left[\mathrm{F}_{1,43}=5.56, \mathrm{p}=.040\right.$ ]; Quantity $\left[F_{1,43}=22.31, p=.001\right]$; Time/Sequence $\left.\left[F_{1,43}=19.11, p=.001\right]\right)$ suggesting that Swedish and Turkish children obtained higher scores in the post-test than the pre-test assessments. Nonsignificant group-time interaction indicates that the rate of improvement from pre-test to post-test assessments was similar for Swedish and Turkish children. Nevertheless, this improvement was not sufficient in helping Turkish children reach their Swedish peers. It appears that the Swedish preschool education programme was not able to close the gap between the Turkish and Swedish children observed prior to program implementation. A body of research literature indicated that pre-school education programs with native language support were effective in supporting immigrant children's language skills, concept development, and school readiness (Becker et al., 2013; Leseman \& Tuijl, 2001; Magnuson et al., 2006; Mushi, 2002; Wilson et al., 2013), a number of studies, on the other hand, suggest that the support provided through pre-school education programs might not be sufficient in helping immigrant children reach their native peers. Previous studies have demonstrated that immigrant status associates with low performances on tasks that assess school readiness and cognitive and language skills (Fröhlich, Petermann \& Metz, 2013; Schonewille \& van der Leij, 1993). Children of Turkish immigrants in Germany tend to perform lower on language test than native children (Yağmur, 2007). Findings of another study in Germany indicate that immigrant children demonstrate lower levels of school readiness than their native peers. Although the duration of preschool experience appears to enhance immigrant children's school readiness, 
immigrant children continue to obtain lower scores on school readiness tasks than their peers who are native speakers of German language (Biedinger, Becker \& Rohling, 2008). Similar findings reported in the context of the United States (Han, Lee \& Waldfogel, 2012). The findings of Han and colleagues' (2012) study demonstrated that preschool education experience do positively impact immigrant children's academic skills, nevertheless immigrant children continue to perform lower on most academic tasks than their native peers. Studies reporting the secondary analysis of the Program for International Student Assessment data demonstrated that despite the legal and pedagogical regulations and reforms the academic achievement gap between the native and immigrant children in Europe persists into the upper grades (Jensen \& Rasmussen, 2011; Pásztor, 2008; Schnepf, 2008; Taguma, Kim, Brink \& Telteman, 2010).

The findings of the present study suggest that Turkish immigrant children do benefit from Swedish preschool education program with language support. Yet, the program fails to close the gap in area of concept acquisition and school readiness between immigrant children and their native peers. This might be due to pedagogical limitations of the Swedish preschool program and implementations (Troike, 1978). These limitations can be enumerated as the pedagogical proficiency of the teacher who offers the native language support, the adequacy of the native language curriculum, the effectiveness of the activities and the convenience of the learning environment. Although the Swedish preschool education program is designed to support the development of immigrant children (Pramling Samuelsson \& Sheridan, 2009; Sheridan \& Pramling Samuelsson, 2001; Stroud, 2002), the implementation fidelity of the program appears to be low (Otterup, 2012a, b).

Providing finance and resources for mother tongue support in preschools depends on the local authorities in Sweden. Due to lack of financial support for mother tongue teaching, the immigrant children's mother tongue development is lower than their Swedish peers. Due to lack of financing mother tongue support is not offered in some areas which adversely affect the development of immigrant children and let them fall behind their Swedish peers (Pavloskaia, 2001). Lack of financing appears to be a serious barrier to effective implementation of the Swedish preschool education program and might be addressed by legal regulations (Karoly \& Gonzalez, 2011).

\section{CONCLUSION AND SUGGESTIONS}

The overall findings of the present study suggest that children in both groups benefited from preschool education program and demonstrated improvement in their concept acquisition and school readiness from pre to post assessments. Nonetheless, the improvement observed in Turkish immigrant children's scores was not adequate to close the gap between the Turkish and Swedish children prior to program implementation.

In the research the effect of the Swedish preschool educational programme are investigated. According to the findings the concept acquisition and school readiness levels of the Turkish children with mother-tongue support and Swedish children were seen to have shown improvement with the pre-school education. However this improvement is in favour of the Swedish children, and when this development is compared with the development of the Turkish children we see that gap is not closed. It is thought that the reasons of this difference are the cultural forms, manners and the support inside the family to the children of the immigrants and also the insufficiency of the pedagogical support given to these children. Nevertheless, the improvement observed in the school readiness and concept acquisition of both groups during the provided pre-school education shows that the programme is effective on both of the groups. 
The results of the current study should be considered as preliminary and interpreted with caution as the study was conducted in a relatively short time span (7 months) with a small sample size. Further studies with a longer duration and larger sample sizes are needed to evaluate the effectiveness of the Swedish preschool education program on immigrant children's conceptual development and school readiness. The current study designed as quantitative models and it is suggested that further researches can be designed as qualitative models. Nevertheless, the findings of this study have important implications for the Swedish policy makers and early childhood educators.

The limitations of this study are there were short time to observe children and research group was small. Since the number of the immigrant Turkish and Swedish immigrant children taking education at the same preschools are insufficient, the study group remained limited. Also, since the research time is conducted at short time project, the amount of time put into observation also limited.

\section{REFERENCES}

Becker, B., Klein, O., \& Biedinger, N. (2013). The development of cognitive, language, and cultural skills from age 3 to 6: a comparison between children of Turkish origin and children of native-born German parents and the role of immigrant parents' acculturation to the receiving society. American Educational Research Journal. 50(3), 616-649.

Behtoui, A. (2004). Unequal opportunities for young people with immigrant backgrounds in the Swedish labour market. Labour. 18(4), 633-660.

Beiser, M.,Hou, F., Hyman, I. \&Tousignant, M. (2002). Poverty, family process, and the mental health of immigrant children in Canada. American Journal of Public Health. 92(2), 220227.

Biedinger, N., Becker, B., \& Rohling, I. (2008). Early ethnic educational inequality: the influence of duration of preschool attendance and social composition. European Sociological Review, 24(2). 243-256

Bracken, B. A. (1984). Bracken basic concept scale examiner's manual. San Antonio, TX: Psychological Corporation.

Bracken, B. A. (1998). Bracken basic concept scale-revised, examiner's manual. San Antoinio: The Psychological Corporation, Harcourt Brace and Company

Bracken, B. A., Sabers, D. \& Insko, W. (1987). Performance of black and white children on the bracken basic. Psychology in the Schools. 24(1), 22-27.

Bracken, B.A. \& Crawford, E. (2010). Basic concepts in early childhood educational standards: a 50-state review. Early Childhood Education Journal. 37, 421-430.

Cohen, C.C., Deterding, N., \& Clewell, B.C. (2005). Who's left behind? Immigrant children in high and low lep schools. Washington, DC: The Urban Institute. Retrieved from http://www.urban.org/UploadedPDF/411231_whos_left_behind.pdf

Cook, T. D., \& Campbell, D. T. (1979). Quasi-experimentation: Design \& Analysis issues for Field Settings. Boston, MA: Houghton Mifflin Company.

De Feyter, J. J., \& Winsler, A. (2009). The early developmental competencies and school readiness of low-income, immigrant children: Influences of generation, race/ethnicity, and national origins. Early Childhood Research Quarterly. 24(4):411-431. 
Dietz, J. (2010). Introduction to the special issue on employment discrimination against immigrants. Journal of Managerial Psychology. 25(2):104-112.

Dotterer, A. M., Iruka, I. U., \& Pungello, E. (2012), Parenting, race, and socioeconomic status: links to school readiness. Family Relations. 61(4), 657-670.

Dronkers, J. (2010). Positive but also negative effects of ethnic diversity in schools on educational performance? An empirical test using cross-national PISA data. MPRA Paper No. 25598. Retrieved from http://mpra.ub.uni-muenchen.de/25598/

European Commission. (2013). Study on educational support for newly arrived migrant children. Luxembourg: Publications Office of the European Union. Retrieved from. http://ec.europa.eu/education/more-information/doc/migrants/report_en.pdf

Eurydice. (2009). Integrating immigrant children into schools in Europe. Eurydice Network Retrieved from. http://eacea.ec.europa.eu/education/eurydice/documents/thematic_reports/101EN.pf

Fleer, M., \& Raban, B. (2006). A Cultural-historical analysis of concept formation in early education settings: conceptual consciousness for the child or only the adult? European Early Childhood Education Research Journal. 14(2),69-80.

Fossati, F. (2011). The effect of integration and social democratic welfare states on immigrants' educational attainment: a multilevel estimate. Journal of European Social Policy. 21(5), 391-412.

Fröhlich, L.P., Petermann, F., \& Metz, D. (2013). Phonological awareness: factors of influence. European Early Childhood Education Research Journal, 21(1):5-22.

Glind van de, H. (2010). Migration and child labour - exploring child migrant vulnerabilities and those of children left-behind, International Labour Office, International Programme on the Elimination of Child Labour (IPEC) - Geneva: ILO

Han, W.J., Lee. R., \& Waldfogel, J. (2012). School readiness among children of immigrants in the US: evidence from a large national birth cohort study. Children and Youth Services Review. 34(4), 771-782.

Heath, A. F., Rothon, C., \& Kilpi, E. (2008). The second generation in Western Europe: education, unemployment, and occupational attainment. Annual Review of Sociology. 34, 211-235.

Ho, R. (2006). Handbook of univariate and multivariate data analysis and interpretation with spss. Florida: Taylor and Francis Group

Jensen, P., \& Rasmussen, A.W. (2011). The effect of immigrant concentration in schools on native and immigrant children's reading and math skills, Economics of Education Review. 30(6), 1503-1515

Jonsson, J.O., \& Rudolphi, F. (2011). Weak performance-strong determination: school achievement and educational choice among children of immigrants in Sweden. European Sociological Review. 27 (4), 487-508.

Karoly, L. A., \& Gonzalez G. C. (2011). Early care and education for children in immigrant families. Journal of the Future of Children. 21(1), 71-101.

Knocke, W. (2000). Integration or segregation? Immigrant populations facing the labour market in Sweden. Economic and Industrial Democracy, 21(3):361-380. 
Korpi, B.M. (2007). The politics of preschool - intentions and decisions underlying the emergence and growth of the Swedish preschool. Stockholm: The Ministry of Education and Research

Leseman, P.P.M., \& Tuijl, C. V. (2001) Home support for bilingual development of Turkish 4-6year-old immigrant children in the Netherlands: efficacy of a home-based educational programme, Journal of Multilingual and Multicultural Development. 22(4), 309-324.

Liebkind, K., Jasinskaja-Lahti, I., \& Solheim, E. (2004). Cultural identity, perceived discrimination, and parental support as determinants of immigrants' school adjustments: Vietnamese youth in Finland. Journal of Adolescent Research. 19(6), 635656.

Lindberg, I. (2007). Multilingual Education: a Swedish Perspective. In M. Carlson, A. Rabo and F. Gök (Eds). Education in 'Multicultural' Societies - Turkish and Swedish Perspectives (pp. 71-90). Stockholm: Swedish Research Institute in Istanbul (Vol.18).

Loeb, S., Fuller, B., Kagan, S. L., \& Carrol, B. (2004). Child care in poor communities: early learning effects of type, quality, and stability. Child Development, 75(1):47-65.

Magnuson, K., Lahaie, C., \& Waldfogel, J. (2006). Preschool and school readiness of children of immigrants. Social Science Quarterly. 87(5), 1241-1262.

Maneva, B. (2004): 'Maman, je suispolyglotte!': A Case study of multilingual language acquisition from 0 to 5 years. International Journal of Multilingualism. 1(2), 109-122.

Matthews, H., \& Even, D. (2010). Early education programs and children of immigrants: learning each other's language. Washington, DC: The Urban Institute.

McCartney, K., Dearing, E., Taylor, B. A., \& Bub, K. L. (2007). Quality child care supports the achievement of low-income children: direct and indirect pathways tthrough caregiving and the home environment. Journal of Applied Developmental Psychology. 28(5-6), 411426.

Mistry, R. S., Biesanz, J. C., Chien, N., Howes, C., \& Benner, A. D. (2008). Socioeconomic status, parental investments, and the cognitive and behavioural outcomes of low-income children from immigrant and native households. Early Childhood Research Quarterly. 23(2), 193-212.

Mushi, S.L.P. (2002). Acquisition of multiple languages among children of immigrant families: parents' role in the home-school language pendulum. Early Child Development and Care. 172(5), 517-530.

National Agency for Education (2006). Curriculum for the Preschool Lpfö 98. Stockholm: Fritzes.

OECD (2001). Starting strong: early childhood education and care, Paris: OECD Publishing. doi: 10.1787/9789264192829-en

OECD (2006). Starting strong II: early childhood education and care. Paris: OECDPublishingRetrieved from http://www.oecd.org/newsroom/37425999.pdf

OECD (2010). Equal opportunities? The labour market integration of the children of immigrants: the labour market integration of the children of immigrants, Paris: OECD Publishing

OECD (2011). Starting srong III: early childhood education and care, Paris: OECD Publishing. doi:10.1787/9789264123564-en 
OECD (2013). Discrimination against immigrants: measurement, incidence and policy instruments, in OECD, International Migration Outlook 2013, OECD Publishing. doi: 10.1787/migr_outlook-2013-7-en

OMEP (2013). About OMEP: world organization for early childhood education. Retrieved from http://www.omep.org.gu.se/about_OMEP/

Otterup, T. (2012a). Multilingual and multicultural schools in Sweden -rhetoric and reality. In E., Winters-Ohle, B. Seipp, B. Ralle, (Eds), Lehrer fürschülermitmigrationsgeschichte sprachlichekompetenzimkontextinternationalerkonzepte der lehrerbildung (pp. 175-182) Münster: Waxmann.

Otterup, T. (2012b). Multilingual development and teacher training in a multicultural society the Swedish example. In E., Winters-Ohle, B. Seipp, B. Ralle, (Eds), Lehrer für Schülermit Migrationsgeschichte - Sprachliche Kompetenzim Kontextinternationaler Konzepte der Lehrerbildung (pp. 164-172) Münster: Waxmann.

Passel, J. S. (2011). Demography of immigrant youth: past, present, and future. The Future of Children. 21(1), 19-41.

Pásztor, A. (2008). The Children of guest workers: Comparative analysis of scholastic achievement of pupils of Turkish origin throughout Europe. Intercultural Education. 19(5), 407-419.

Pavlovskaia, E. (2001). Education of immigrant children at the pre-school level in Sweden: an empirical study of how the education of immigrant children is conducted in practice. (Master Thesis, Department of Education, Lund University, Lund, Sweden) Retrived

from http://lup.lub.lu.se/luur/download?func=downloadFile\&recordOId=1356970\&fileOId=1 356971

Pramling Samuelsson, I., \& Sheridan, S. (2009). Preschool quality and young children's learning in Sweden. International Journal of Child Care and Education Policy. 3(1), 1-11.

Rao, N., Sun, J., Zhou, J., \& Zhang, L. (2012). Early achievement in rural china: the role of preschool experience. Early Childhood Research Quarterly. 27(1), 66-76.

Rindermann, H., \&Ceci, S.J. (2009). Educational Policy and country outcomes in international cognitive competence studies. Perspectives on Psychological Science. 4(6), 551-568.

Rumbaut, R. G. (1997). Ties that bind: immigration and immigrant families in United States, in A. Booth, A.C. Crouter, N. Landale (Eds.) Immigration and the family: research and policy on US immigrants, (pp. 3-46), New Jersey: Lawrence Erlbaum Associates.

Safi, M. (2010). Immigrants' Life Satisfaction in Europe: Between Assimilation and Discrimination. European Sociological Review. 26 (2), 159-176.

Schnepf, S.V. (2008). Inequality of learning amongst Immigrant children in Industrialised countries. The Institute for the Study of Labour. Discussion Paper No: 3337 Available at http://dx.doi.org/10.1111/j.0042-7092.2007.00700.x

Schonewille, B., \& van der Leij, A. (1993). Ethnic background, classroom instruction and child behaviour in kindergarten: the role of the teacher to stimulate children in the classroom by giving individual attention. European Early Childhood Education Research Journal. 1(2), 11-25. 
Sheridan, S., \& Pramling Samuelsson, I. (2001). Children's conceptions of participation and influence in preschool: A perspective on pedagogical quality. Contemporary Issues in Early Childhood. 2(2), 169-194.

Shields, M.K., \& Behrmen, R. E. (2004). Children of immigrant families: analysis and recommendations. The Future of Children. 14(2), 4-15.

Skolverket (2008a). With another mother tongue-students in compulsory school and the organization of teaching and learning, Stockholm: National Agency for Education Report 321.

Skolverket (2008b). Ten years after the preschool reform: A national evaluation of the Swedish preschool. Stockholm: National Agency for Education Report 318.

Skolverket (2009). Educational results national level: Sweden's official statistics on pre-school activities, school-age child-care, schools and adult education. (Report 2009:325). Stockholm: Swedish National Agency for Education

Skolverket (2011). Curriculum for the Preschool Lpfö 98: Revised 2010, Stockholm: National Agency for Education

Stebbish, M.S., \& McIntosh, D.E. (1996).Decision-Making utility of the bracken basic concept scale in identifying at-risk pre-schoolers. School Psychology International. 17(3), 293303.

Stroud, C. (2002). Towards a policy for bilingual education in developing countries. Stockholm: Swedish International Development Cooperation Agency (SIDA) Department for Democracy and Social Development, DESO Education Division, New Education Division Documents No. 10.

Taguma, M., Kim, M., Brink, S., \& Telteman, J. (2010). OECD reviews of migrant education Sweden. Paris: OECD.

Taguma, M., Litjens, I., \& Makowiecki, K. (2013). Quality matters in early childhood education and care: Sweden 2013. Paris: OECD Publishing. Retrieved from http://www.oecd.org/edu/school/SWEDEN\%20policy\%20profile\%20\%20published\%200 5-02-2013.pdf

Tienda, M., \& Haskins, R. (2011). Immigrant children: introducing the issue. The Future of Children. 21(1), 3-18.

Toran, M., \& Temel, F.Z. (2012). Examination of Turkish preschool curriculum's effect on children's concept acquisition. Procedia-Social and Behavior Sciences Journal. 47, 594599.

Troike, R.C. (1978). Research evidence for the effectiveness of bilingual education. Bilingual Research Journal. 3(1), 13-24.

UNICEF (2004). Çocuk haklarına dair sözleşme. Ankara: Unicef Türkiye. Retrieved from http://www.unicef.org/turkey/pdf/_cr23.pdf

Üstün, E., \& Akman, B. (2003). Üç yaş grubu çocuklarda kavram gelişimi. Hacettepe Üniversitesi Eğitim Fakültesi Dergisi. 24, 137-141.

Vosniadou, S., Pagondiotis, C., \& Deliyianni, M. (2005). From the pragmatics of classification systems to the metaphysics of concepts. The Journal of the Learning Sciences. 14(1), 115-125. 
Warren, A. R. (2013). Mother tongue tuition in Sweden - curriculum analysis and classroom experience. International Electronic Journal of Elementary Education. 6(1), 95-116.

Whitehead, A. Hashim, I.M., \& Iversen, V. (2007). Child migration, child agency and intergenerational relations in Africa and south Asia, paper presented Children and Youth in Emerging and Transforming Societies International Conference in Oslo, 29 June -3 July 2005. Retrived from http://www.migrationdrc.org/publications/working_papers/WPT24.pdf

Wilson, P. (2004). A preliminary investigation of an early intervention program: examining the Intervention effectiveness of the bracken concept development program and the bracken basic concept scale-revised with head start students. Psychology in the Schools. 41(3), 301-311.

Wilson, S.J., Dickinson, D.K., \& Rowe, D.W. (2013). Impact of an early reading first program on the language and literacy achievement of children from diverse language backgrounds. Early Childhood Research Quarterly. 28(3), 578-592.

Yağmur, K. (2007). İki dilli çocukların dil becerilerinin ölçümü ve eşik kuramı. Dil Dergisi. 135, 60-76.

YazıcI, Z., Genç İlter, B., \& Glover, P. (2010). How bilingual is bilingual? Mother tongue proficiency and learning through a second language. International Journal of Early Years Education. 18(3), 259-268. 


\section{GENIŞ ÖZET}

Sosyoekonomik dezavantaj olarak kabul edilen ve sürekli gündemde olan göç olgusu, birçok problemi beraberinde getirmektedir. Yeni kültüre uyum, sosyal ortamda kabul görme, kendini ifade etme, yaşamı sürdürebilme ve yeniden var olabilme sorunları göç eden aileyi doğrudan etkilediği kadar çocuğunu da doğrudan etkilemektedir. Göç eden ailelerin çocuklarının gelişimsel becerilerinin desteklenmesi bu anlamda büyük bir önem taşımaktadır. Göçmen ailelerinin çocukları sadece göçmenliğin dezavantajlarına sahip değil, aynı zamanda yeni bir kültür ve dil kuşatması altında oldukları için özellikle akademik ve sosyal alanlarda güçlükler ile karşı karşıya gelmektedirler. Bu olgu tek taraflı gerçekleşen bir durum olmamakla birlikte göç edilen toplumdaki bireylerin davranış biçimlerini de değiştirebilmektedir. Göçmen ailelerin çocukları ile yapılan araştırmalar, bu gruptaki çocukların risk grubunu oluşturduğunu göstermektedir. Göçmen çocuklarının yoksullukla karşı karşıya oldukları ve yoksulluğun yarattığı dezavantajlı durumlardan olumsuz bir şekilde etkilendiği bilinmektedir. Yoksulluk çocukların aynı zamanda yoksunlukla karşı karşıya gelmesine de neden olmaktadır. Bu yoksunluk, çocukların zengin uyarıcı çevreden yararlanamamalarına neden olmakta ve nitelikli bir şekilde eğitimlerine devam etmelerinin önünde büyük bir engel oluşturmaktadır. Göç olgusu aynı zamanda göç eden ailelerin çocuklarının okul başarısı ile birlikte okula devam durumlarının düşük oranda kalmasına neden olmakta ve gelişim alanlarında ilerlemenin normalin altında kalmasına da yol açabilmektedir.

Göç olgusunun yarattığı dezavantaj çocukların bilişsel becerilerinden olan bilgiyi yapılandırma, okula hazırlık düzeyi ve kavram edinimi üzerinde olumsuz bir etkiye sahiptir. Göç olgusunun en fazla olumsuz etkilediği erken yıllar kritik bir öneme sahip olmakla birlikte çocuklar korunmasız bir şekilde göçün yarattığı tüm etkilere maruz kalmaktadırlar. Bu etkiler çocukların dünyayı algılamalarına, kendilerini bilişsel olarak düzenlemelerine, kendilerini ifade etmelerine ve akademik olarak başarılı olmalarına engel olmaktadır. Bu anlamda göç eden ailelerin çocuklarının kavram edinimi ve okula hazırlık düzeylerinin incelenmesi araştırmanın önemini ortaya koymaktadır. Mevcut araştırma, anadili eğitimi ile bütünleştirilmiş İsveç okul öncesi eğitimi programının çocukların okula hazırlık düzeyleri ve kavram edinimleri üzerindeki etkilerinin incelenmesini amaçlamaktadır. Araştırmanın temel sınırlılığı, araştırma süresinin kısa olması, aynı eğitim ortamında eğitim gören anadili desteği alan Türkiyeli ve İsveçli çocukların sayısının yeterli olmamasından kaynaklı ulaşılan çocuk sayısının az olmasıdır.

Araştırmada yöntem olarak eşitlenmemiş kontrol gruplu (nonequivalent control group) desen kullanılmıştır. Çalışma grubunu Göteborg'da kamuya ait okul öncesi eğitim kurumlarına devam eden ve aynı sınıfta birlikte eğitim alan çocuklardan oluşturulmuştur. Araştırmanın çalışma grubunu 23'i İsveçli ve 22'i Türkiyeli olmak üzere, 5 yaşında toplam 45 çocuk oluşturmaktadır. Türkiyeli göçmen aile çocukları okul öncesi eğitim kurumunda anadili desteği alan çocuklardan seçilmiştir. Araştırmanın gerçekleştirilebilmesi için öncelikle ailelerden sonrasında ise okullarından çocukların araştırmaya katılması için etik izin alınmıştır. Araştırmada veri toplama aracı olarak Bracken Temel Kavram ÖlçeğiGözden Geçirilmiş Formu (BTKÖ) kullanılmıştır. BTKÖ 11 alt ölçekten ve 308 maddeden oluşmaktadır. Ölçekteki alt testler okula hazırlık, yön/konum, bireysel/sosyal farkındalık, yapı/materyal, miktar ve zaman/sıralama şeklindedir. Ölçeğin gecerlik ve güvenirliği için İsveççeye uyarlama çalışması yapılmıştır. BBCS-R orijinal İngilizce formundan İsveççeye dil uzmanı tarafından çevrilmiş ve daha sonra iki farklı dil uzmanından görüş alınarak ölçeğe son hali verilmiştir. Güvenirlik için 59 çocuğa uygulama yapılmış ve Cronbach Alpha güvenirlik katsayısı alt ölçeklerde sırasıyla okula hazırlık .74, yön/konum .75, bireysel/sosyal farkındalık .78, yapı/materyal .79, miktar .77 ve zaman/sıralama .79, BBCS-R ölçek toplam değeri ise .91 bulunmuştur. Gerçekleştirilen uygulamalarda ölçeğin anadili İsveççe olan ve olmayan çocukları ayırt ettiği tespit edilmiştir. Verilerin analizi için uygun olan verilere normallik testleri uygulanarak uygun istatistiksel analizler kullanılmıştır.

Araştırmada, anadili desteği alan Türkiyeli çocuklar ile İsveçli çocukların okula hazırlık ve kavram edinimi üzerinde İsveç okul öncesi eğitim programının etkisi incelenmiştir. Araştırmanın veri toplama aracından elde edilen bulgulara göre, anadili desteği alan Türkiyeli çocuklar ile İsveçli çocukların okula hazırlık düzeyleri ile kavram edinimleri alınan okul öncesi eğitim ile pozitif yönde ilerleme göstermiştir. Ancak bu ilerlemenin İsveçli çocuklar lehine olduğu, Türkiyeli göçmen çocuklarda gözlenen ilerlemenin karşılaştırma yapıldığında gruplar arasındaki farkı kapatamadığı görülmektedir. Bu farklılıkların göçmen çocukların aleyhine olması, bu çocukların evde maruz kaldıkları kültürel formların, tutumların ve aile 
içerisinde çocuğa sunulan desteğin farklılık göstermesinden kaynaklanabileceği düşünülmekle birlikte göçmen çocuklara sunulan pedagojik desteğin göçmen çocukların ihtiyaçlarını karşılayamamasının da sebep olabileceği düşünülmektedir. Buna rağmen, alınan okul öncesi eğitim süresince okula hazırlık ve kavram ediniminin her iki grupta da ilerleme göstermesi alınan okul öncesi eğitim programının gruplar içinde etkili olduğunu göstermektedir.

Sonuç olarak İsveç'te çocuklara sunulan okul öncesi eğitim programının çocukların okula hazırlık ve dil becerileri üzerinde etkili olduğu ve bununda çocukların kavram edinim performanslarını doğrudan etkilediğini, kültürel farklılıklardan kaynaklı dezavantajların eğitim süresince kısmen de olsa giderildiği söylenebilir. Araştırma sonuçlarının etnik kökenleri fark etmeksizin çocukların lehine olması, okul öncesi eğitim programlarının tasarlanmasında karar vericiler için yol gösterici nitelikte olmakla birlikte, özellikle çok kültürlü toplumlarda okul öncesi eğitimi alanında politikaların geliştirilmesine yön verebileceği düşünülmektedir.

Araştırmada çalışılan çocuk sayısının azlığı araştırmanın sınırlıı̆̆ı olarak kabul edildiği için sonraki araştırmaların sayısal olarak daha büyük bir çocuk grubu ve diğer etnik gruplardaki çocukları da kapsayacak şekilde araştırmaların yapılması önerilmektedir. Bununla birlikte araştırmanın süresinin kısa olması da yine araştırmanın sınırlılığı olarak kabul edilmiş dolayısıyla araştırmaların uzun süreli olarak tasarlanması ve boylamsal çalışmaların yapılması önerilmekte ve bu tür çalışmalarla erken çocukluk eğitimine yönelik politika, program ve yaklaşımlar için stratejilerin belirlenmesine ön ayak olunabilir. 